\title{
Concentrations of a Koi herpesvirus (KHV) in tissues of experimentally infected Cyprinus carpio koi as assessed by real-time TaqMan PCR
}

\author{
Oren Gilad ${ }^{1}$, Susan Yun ${ }^{1}$, Francisco J. Zagmutt-Vergara ${ }^{1}$, \\ Christian M. Leutenegger ${ }^{1,2}$, Herve Bercovier ${ }^{3}$, Ronald P. Hedrick ${ }^{1, *}$ \\ ${ }^{1}$ Department of Medicine and Epidemiology, School of Veterinary Medicine, University of California, Davis, \\ California 95616, USA \\ ${ }^{2}$ Lucy Whittier Molecular and Diagnostic Core Facility, University of California, Davis, California 95616, USA \\ ${ }^{3}$ Institute of Microbiology, Department of Clinical Microbiology, The Hebrew University-Hadassah Medical School, \\ Ein Karen, Jerusalem, Israel
}

\begin{abstract}
The Koi herpesvirus (KHV) is a herpes-like virus now recognized as a worldwide cause of mortality among populations of koi Cyprinus carpio koi and common carp Cyprinus carpio carpio. Temperature is a key factor influencing virus replication both in cell culture and in the tissues of experimentally infected fish. Genomic DNA sequences were used to optimize a rapid real-time TaqMan PCR assay to detect and quantify KHV DNA as found in the tissues of virus-exposed fish. The assay allowed analytical enumeration of target KHV genome copies ranging from $10^{1}$ to $10^{7}$ molecules as present in infected cell lines or fish tissues. The new assay was specific for KHV and did not detect DNA from 3 related herpes-like viruses found in fish, the Cyprinid herpesvirus 1 (CyHV-1), Cyprinid herpesvirus 2 (CyHV-2), Ictalurid herpesvirus 1 (IcHV-1) or the KF-1 cell line used for virus growth. Concentrations of KHV DNA were evaluated in 7 different tissues of replicate groups of virus-exposed koi held at water temperatures of 13, 18, 23 and $28^{\circ} \mathrm{C}$. Viral DNA was detected among virus-exposed koi at all 4 water temperatures but mortality was only observed among fish at 18, 23, and $28^{\circ} \mathrm{C}$. Time and temperature and the interactions between them affected concentrations of viral DNA detected in tissues of koi exposed to KHV. Although there were no recognized patterns to viral DNA concentrations as found in different tissues over time, KHV genome copies for all tissues increased with time post virus exposure and with water temperature. The remarkably rapid and systemic spread of the virus was demonstrated by the presence of viral DNA in multiple tissues $1 \mathrm{~d}$ post virus exposure. The greatest DNA concentrations found were in the gill, kidney and spleen, with virus genome equivalents consistently from $10^{8}$ to $10^{9}$ per $10^{6}$ host cells. High levels of KHV DNA were also found in the mucus, liver, gut, and brain. Koi surviving infection at 62 to $64 \mathrm{~d}$ post virus exposure contained lower KHV genome copies (up to $1.99 \times 10^{2}$ per $10^{6}$ host cells) as present in gill, kidney or brain tissues.
\end{abstract}

KEY WORDS: TaqMan PCR · Herpes-like viruses $\cdot$ Koi herpesvirus $\cdot$ KHV $\cdot$ Cyprinus carpio koi Resale or republication not permitted without written consent of the publisher

\section{INTRODUCTION}

In 1998, a herpes-like virus, designated Koi herpesvirus (KHV), was isolated from koi Cyprinus carpio koi in Israel and the USA undergoing outbreaks of a serious and apparently new disease (Hedrick et al. 1999, 2000). Bath exposures of juvenile koi with KHV grown in KF-1 cells reproduced gross and microscopic pathological signs and high mortality similar or identical to that observed in naturally occurring outbreaks (Hedrick et al. 2000).

The first observations of herpes-like virus particles in the gill epithelium of koi were reported in 1997 in Germany (Bretzinger et al. 1999). Subsequently, 
several viruses were isolated from koi with gill and skin diseases by Body et al. (2000) in Belgium, Neukirch et al. (1999) in Germany, and Oh et al. (2001) in Korea. Upon further examination, these viruses were all found to differ from KHV with respect to either virion morphology, cytopathic effects, susceptibility of cell lines, or ability to cause disease upon exposure of koi. Thus, none of these viral agents were suspected causes of the new disease in koi. That KHV was the cause of the disease among koi and common carp was further confirmed by more recent reports by Neukirch \& Kunz (2001), Ronen et al. (2003) and Perelberg et al. (2003), although Ronen et al. (2003) preferred carp nephritis and gill necrosis virus (CNGV) as a designation for the virus.

Since 1998, the virus has spread through largely unregulated movements of koi and other unknown means. The virus or evidence for KHV has now been found in several European countries, the USA, Indonesia and most recently in koi and wild common carp in Japan (Rukyani 2002, O. Haenen \& M. Sano pers. comm.).

Two other herpes-like viruses have been recognized as causing serious diseases among cyprinid fishes. Cyprinid herpesvirus 1 (CyHV-1), also referred to as cyprinid herpesvirus (CHV), was first isolated from koi and common carp in 1981 (Sano et al. 1985a,b). The virus causes mortality among koi and common carp younger than 2 mo in age and survivors may develop the characteristic papillomatous-like growths commonly known as carp pox (Schubert 1966). A second herpes-like virus, Cyprinid herpesvirus 2 (CyHV-2), also designated goldfish hematopoietic necrosis virus (GFHNV), was observed by electron microscopy and isolated from goldfish Carassius auratus with severe hematopoietic necrosis (Jung \& Miyazaki 1995). The initial isolates of CyHV-2 were lost and the virus has proven difficult to reisolate (Groff et al. 1998, authors' unpubl. obs.). Comparisons of the genomic DNA and virion polypeptides of KHV to CyHV-1 suggest the viruses are related but clearly different and this has allowed specific detection of the agents with newly developed PCR assays (Gilad et al. 2002, Gray et al. 2002). Important biological features distinguish the 3 cyprinid herpes-like viruses CyHV-1, CyHV-2 and KHV. KHV differs from CyHV-1 by causing disease and mortality among all sizes of koi and common carp (Bretzinger et al. 1999, Hedrick et al. 2000, Perelberg et al. 2003) rather than just among koi and common carp less than 2 mo of age (Sano et al. 1985a,b). In addition, there is no formation of the papillomatous growths among fish surviving KHV infection. Lastly, goldfish, which are highly susceptible to CyHV-2, are refractive to KHV infections and conversely CyHV-2 failed to cause disease among koi injected with the virus (Jung \& Miyazaki 1995, Bretzinger et al. 1999, Perelberg et al. 2003, Ronen et al. 2003, authors' unpubl. results).

A presumptive diagnosis of KHV disease includes observation of high mortality despite treatments for bacterial and or external parasites among koi and common carp with characteristic external pathological signs at water temperatures ranging from 18 to $26^{\circ} \mathrm{C}$. The external signs seen in sick fish include swollen and necrotic gill filaments, excessive mucus production or discolored patches on the skin, and sunken eyes (Walster 1999, Hedrick et al. 2000). Internally, the kidney and spleen may be enlarged. Confirmatory diagnoses require demonstrations of the presence of virus by isolation using KF-1 or other KHV susceptible cells followed by PCR testing of virus isolates or fish tissues directly by one of 2 PCR assays (Gilad et al. 2002, Gray et al. 2002). Unfortunately, it is often difficult to isolate or to enumerate concentrations of KHV from infected koi using cell culture methods, particularly if the fish have been dead for several hours or have been frozen. Detection may therefore, rely solely on the PCR results obtained from fish tissues.

The principal target tissues for KHV based on microscopic pathological exams of naturally and experimentally infected koi are suspected to be the gill, kidney and spleen but other tissues including the brain, gut and liver are also involved (Hedrick et al. 2000, Gray et al. 2002, Gilad et al. 2003). Current diagnostic approaches most often use portions of the gill, kidney and spleen for virus isolation and or PCR analysis. These approaches have not demonstrated the ability to routinely detect virus or viral DNA in the tissues of suspected carriers of KHV, which is viewed as important to controlling the spread of the virus.

A key environmental factor influencing KHV outbreaks in koi and common carp is water temperature. The disease occurs principally in the spring and autumn when water temperatures range from 18 to $26^{\circ} \mathrm{C}$ (Bretzinger et al. 1999, Hedrick et al. 2000, Perelberg et al. 2003). As demonstrated from both field and laboratory trials, infections obtained at lower water temperatures occur in the absence of clinical signs but upon transfer to permissive temperatures fish undergo acute episodes and mortality (Bretzinger et al. 1999, Gilad et al. 2003). Optimal growth of the virus in the koi fin cell line (KF-1) occurs at 20 to $25^{\circ} \mathrm{C}$ with no growth at 30 or $4^{\circ} \mathrm{C}$ and limited growth at $10^{\circ} \mathrm{C}$ (Gilad et al. 2003). The temperature limits of the virus have been exploited in an effort to control the disease in fish culture facilities. Regimens of exposure to virus at permissive temperatures followed by shifts to higher temperatures $\left(30^{\circ} \mathrm{C}\right)$ have been utilized for koi bound for export in Israel (Ronen et al. 2003). These temperature treatments have significantly reduced mortality due to 
the disease and fish surviving the process are marketed as 'immune'. Viral DNA is not found by conventional PCR in tissues examined from 'immune' fish which experience considerably reduced mortality (39\% compared to $80-90 \%$ in controls) upon re-exposure to the virus (Ronen et al. 2003). Lastly, cohabitation of 'immune' fish with naïve fish is reported not to result in disease transmission (Ronen et al. 2003).

Improved diagnostic methods for detecting KHV throughout and following the acute phase of the disease including suspected carriers or healthy appearing infected fish at low water temperatures are needed. A procedure that also effectively determines the concentrations of virus in tissues would also allow for further studies of the pathogenesis of KHV infections. In general, real-time TaqMan PCR has been shown to detect and quantitatively assess very low copy numbers of target molecules (Clementi 2000, Mackay et al. 2002). The real-time TaqMan PCR has more recently moved from a research to a common diagnostic procedure in mammals (Leutenegger et al. 1999, Berger \& Preiser 2002) and fish (Dhar et al. 2001, Overturf et al. 2001, del Cerro et al. 2002). The TaqMan PCR offers levels of target detection equivalent to or better than most conventional PCR tests but avoids dangers of contamination inherent to nested PCR assays by minimizing the handling of samples through automation during sample preparation and thermal cycling procedures.

Here we describe the development of a real-time TaqMan PCR for KHV that can be used to detect and quantify KHV DNA in infected fish. The assay was then used to assess concentrations of target viral DNA as found in tissues of experimentally infected koi held at water temperatures of $13,18,23$ and $28^{\circ} \mathrm{C}$ at selected times following virus exposure.

\section{MATERIALS AND METHODS}

Virus strains. The KHV (KHV-I) used in this study was isolated from adult koi experiencing mass mortal- ity in Israel in 1998 (Hedrick et al. 2000). The CyHV-1 in this study was a gift from Dr. T. Sano and Dr. H. Fukuda, Tokyo University of Fisheries. Kidney tissues from goldfish with CyHV-2 infections were a kind gift of Dr. S. LaPatra, Clear Springs Food Inc. The Ictalurid herpesvirus 1 (IcHV-1), also known as channel catfish virus (CCV) strain CA80-5, as isolated from an epizootic among juvenile channel catfish Ictalurus punctatus in California in 1980 (Arkush et al. 1992) was used as an example of a herpes-like virus from fish more distantly related to KHV. Viruses were grown in the appropriate cell line and the concentrations estimated as described previously (Hedrick et al. 2000, Gilad et al. 2003).

Nucleic acid extraction from purified virions. KHV and $\mathrm{CyHV}-1$ grown in KF-1 cells and IcHV-1 grown in channel catfish ovary (CCO) cells were purified and genomic DNA extracted as described by Gilad et al. (2002). The DNA from uninfected KF-1 cells was prepared by the same procedure as that for purified virus.

Plasmid preparation for TaqMan quantitation. A plasmid carrying a KHV genome insert was prepared as described by Gilad et al. (2002). Briefly, genomic DNA purified from KHV virions was incubated with $10 \mathrm{U}$ of $\mathrm{KpnI}$ and $\mathrm{SaCI}$ endonucleases. The resulting DNA fragments were inserted into the pGEM@-7Zf $(+)$ plasmid that was then used to transform DH5 $\alpha$ Escherichia coli cells. Bacterial cells harboring KHV inserts were selected and screened by PCR using SP6/T7 primers flanking the insert site (Sambrook et al. 1989). The sequence of inserts was obtained by fluorescently labeled dideoxy terminator sequencing using an $\mathrm{ABI}$ 377 automated DNA sequencer (Applied Biosystems). The KHV TaqMan assay was developed from the insert designated AF411803.

Real-time quantitative PCR system. For each target sequence, 2 primers and an internal fluorescently labeled TaqMan probe (Table 1) were designed as described by Leutenegger et al. (1999). In addition to a TaqMan PCR detecting sequences of KHV insert AF411803, a second assay was developed targeting an

Table 1. Primer sequences and probes specific for a newly developed real-time TaqMan PCR to detect KHV and the Cyprinus carpio glucokinase gene (as an internal control). Also shown are the TaqMan product length and the GenBank accession numbers

\begin{tabular}{|c|c|c|c|c|c|c|}
\hline Target & Primer & Sequence $\left(5^{\prime} \rightarrow 3^{\prime}\right)$ & Length & Probe & Probe sequence $\left(5^{\prime} \rightarrow 3^{\prime}\right)$ & Accession no. \\
\hline \multirow[t]{2}{*}{ KHV } & KHV-86f & $\begin{array}{c}\text { GACGCCGGAG- } \\
\text { ACCTTGTG }\end{array}$ & 78 & KHV-109p & $\begin{array}{c}\text { CTTCCTCTGCTCG- } \\
\text { GCGAGCACG }\end{array}$ & AF411803 \\
\hline & KHV-163r & $\begin{array}{c}\text { CGGGTTCTTATTT- } \\
\text { TTGTCCTTGTT }\end{array}$ & & & & \\
\hline \multirow[t]{2}{*}{ Glucokinase } & CgGluc-162f & $\begin{array}{c}\text { ACTGCGAGTGGA- } \\
\text { GACACATGAT }\end{array}$ & 69 & cgGluc-185p & $\begin{array}{l}\text { AAGCCAGTGTCAA- } \\
\text { AATGCTGCCCACT }\end{array}$ & AF053332 \\
\hline & CgGluc-230r & $\begin{array}{l}\text { TCAGGTGTGGA- } \\
\text { GCGGACAT }\end{array}$ & & & & \\
\hline
\end{tabular}


exonic sequence of the koi glucokinase (AF053332), a known single copy gene from common carp (Panserat et al. 2000). This second TaqMan assay served as a genomic DNA extraction control for enumeration of the number of host cells present in each assay (Tanizawa et al. 1992). Exon positions were extrapolated from human glucokinase sequences (XM_041002) and verified on genomic DNA from koi. The length of the PCR products were kept purposely short (between 69 and $78 \mathrm{bp}$ ) to enable high amplification efficiencies. Primer and probe sequences and relevant information to the TaqMan PCR for KHV are listed in Table 1. The least amount of target DNA detectable with the TaqMan PCR assay was determined using 10-fold serial dilutions from $10^{7}$ to 0 copies of the plasmid bearing the KHV insert.

Sample preparation for TaqMan PCR. Tissue samples (approximately 20 to $50 \mathrm{mg}$ ) obtained from freshly sacrificed koi were stored at $-80^{\circ} \mathrm{C}$. Before DNA extraction, the tissues were transferred frozen into 96-deep-well plates containing $800 \mu \mathrm{l}$ of $1 \times$ ABI lysis buffer (Applied Biosystems) and 2 grinding beads (4 mm diameter, SpexCertiprep). Tissue samples were ground in a GenoGrinder2000 (SpexCertiprep) for $2 \mathrm{~min}$ at 1000 strokes per min. After $30 \mathrm{~min}$ at $4^{\circ} \mathrm{C}$, genomic DNA was extracted from the tissue lysates with a 6700 automated nucleic acid (ANA) workstation (Applied Biosystems) according to the manufacturer's instructions.

Source of fish. Koi used in the experimental trial were from a closed-system commercial ornamental fish producer in California with no history of KHV infection. The fish were transported live to the Fish Health Pathogen Containment Laboratory at the University of California, Davis. The fish were held in $130 \mathrm{l}$ flow-through aquaria receiving $18^{\circ} \mathrm{C}$ well-water at $1.81 \mathrm{~min}^{-1}$, and were fed a commercial koi ration at $1 \%$ body weight per day. At the time of experimentation these fish were approximately $2 \mathrm{yr}$ in age with a mean weight of $0.274 \mathrm{~kg}$ and a mean length of $23 \mathrm{~cm}$.

Virus exposures of fish. Just prior to the initiation of the experiment all fish were combined into one $800 \mathrm{l}$ aquarium. Fish were randomly assigned to 8 aquaria by drawing numbers from a common pool such that each 1301 aquarium eventually contained 20 or 21 fish. All fish were initially at a water temperature of $18^{\circ} \mathrm{C}$. Acclimation to each of the 3 other water temperatures $\left(13,23\right.$, or $\left.28^{\circ} \mathrm{C}\right)$ for the trial was accomplished by lowering or increasing the water temperature in increments of $3^{\circ} \mathrm{C} \mathrm{d}^{-1}$ until the desired temperature was obtained. There were 2 replicate aquaria at each water temperature. Fish in one aquarium at each temperature received a bath exposure to $12 \mathrm{TCID}_{50} \mathrm{ml}^{-1}$ of KHV grown in KF-1 cells, whereas the fish in the second aquaria at each temperature were treated identi- cally to the virus-exposed groups but received only minimal essential media (MEM) with no virus. During the virus or MEM exposure period the water flow was stopped and oxygen was bubbled into each aquarium for a period of $1 \mathrm{~h}$. After the exposure, the flow of water to all aquaria was resumed. Two fish were removed for sampling at the following time points post exposure; $1,2,3,6,10,16$, and 62 or $64 \mathrm{~d}$. Fish were sacrificed by placement into a container with $500 \mathrm{mg}$ benzocaine per liter of water. Selected tissues (mucus from a lateral side, gill, gut, liver, spleen, kidney, and brain) from each fish were examined for target KHV DNA by realtime TaqMan PCR. Not all samples collected at selected time points were examined by the TaqMan PCR assay. In most cases the mean value KHV genome equivalents for $10^{6}$ host cells for 2 fish were calculated at each time point but in some instances tissues were from a single fish. Fish that died at or between sampling periods were removed and tested as described for fish sampled at prescribed time points.

Quantification of KHV target in tissue samples. The quantity of KHV target DNA in koi tissues was determined with a modification of the comparative $\mathrm{CT}$ method (User Bulletin \#2, Applied Biosystems) and is reported as the absolute number of KHV genomes per $10^{6}$ host cells from a given tissue by using the TaqMan PCR systems as described above. The same volume of gDNA was tested for glucokinase and KHV in parallel and the genome equivalent extrapolated from a standard curve generated with a cloned glucokinase TaqMan PCR product. The ability of the TaqMan PCR to detect KHV as present in uninfected kidney tissues seeded with virus grown in KF-1 cells was also evaluated. A kidney from a single unexposed koi was divided into 8 equal portions $(0.05 \mathrm{~g})$ in a 96 -well dish. A serial 10-fold dilution series of KHV beginning with $10^{0}$ (undiluted) to $10^{-6}$ was prepared in minimal essential medium containing $2 \%$ fetal bovine serum (MEM-2) and $0.5 \mathrm{ml}$ from each dilution was used to inoculate 7 kidney samples. The 7 virus-inoculated and the one uninoculated kidney tissues were then prepared for TaqMan analyses as described previously. The concentrations of KHV present in the same dilutions of KHV used to inoculate the tissue samples were used to inoculate replicate wells of multi-well dish containing KF-1 cells to determine the $50 \%$ tissue culture infective dose as previously described (Reed \& Meunch 1938).

Statistical analyses. The relationship of viral DNA concentrations with respect to time post-virus-exposure, tissue and water temperature was evaluated using 3-way analysis of variance (ANOVA) over logtransformed DNA values to achieve normality assumptions of the test. Significant terms on the final model were selected in a stepwise fashion using 
likeihood ratio tests. Differences between levels of selected variables found significant in the final ANOVA model were assesed with multiple comparison analyses using the Bonferroni method. All analyses were performed using S-Plus 6.1 (Insightful Corp.).

\section{RESULTS}

\section{Optimization of the real-time TaqMan PCR assay}

The optimal parameters for the real-time TaqMan PCR assay were obtained by sequential testing of target DNA from purified plasmid and later from experimentally virus-exposed koi (Hedrick et al. 2000, Gilad et al. 2002). Each TaqMan reaction contained $400 \mathrm{nM}$ of each primer, $80 \mathrm{nM}$ of the TaqMan probe in commercially available PCR mastermix (TaqMan Universal PCR Mastermix, Applied Biosystems), 10 mM Tris- $\mathrm{HCl}$ (pH 8.3), $50 \mathrm{mM} \mathrm{KCl}, 5 \mathrm{mM} \mathrm{MgCl} 2,2.5 \mathrm{mM}$ deoxynucleotide triphosphates, $0.625 \mathrm{U}$ AmpliTaq Gold DNA polymerase, $0.25 \mathrm{U}$ AmpErase $\mathrm{UNG}$, and $5 \mu \mathrm{l}$ of the diluted DNA sample in a final volume of $25 \mu \mathrm{l}$. The samples were than placed in 96-well plates and assayed in an automated fluorometer (ABI PRISM 7700 Sequence Detection System, Applied Biosystems). The optimized conditions are $2 \mathrm{~min}$ at $50^{\circ} \mathrm{C}, 10 \mathrm{~min}$ at $95^{\circ} \mathrm{C}$, 40 cycles of $15 \mathrm{~s}$ at $95^{\circ} \mathrm{C}$ and $60 \mathrm{~s}$ at $60^{\circ} \mathrm{C}$.

\section{Specific detection and enumeration of KHV}

The real-time TaqMan PCR assay under optimal conditions amplified a $78 \mathrm{bp}$ fragment of DNA from $\mathrm{KHV}$ and not from CyHV-1, CyHV-2, IcHV-1, control koi tissues or the KF-1 cell line. The CT value for TaqMan PCR detection of all samples other than KHV was greater than 40 (cycles) a limit that is considered negative. In contrast, the value for KHV was 32.05 which corresponded to approximately 100 genome equivalents per $10^{6}$ host cells. The TaqMan PCR was able to detect KHV DNA in kidney tissues seeded with dilutions of KHV as grown in KF-1 cells. Genome equivalents of KHV per $10^{6}$ host cells for the dilutions of $10^{0}$, $10^{-1}, 10^{-2}, 10^{-3}$ and $10^{-4}$ were $9.34 \times 10^{8}, 1.32 \times 10^{7}$, $1.71 \times 10^{6}, 8.20 \times 10^{5}$ and $6.01 \times 10^{3}$, respectively. Viral cytopathic effects (CPE) were observed in all 5 replicate wells of KF-1 cells at each dilution from $10^{\circ}$ to $10^{-4}$. No KHV DNA was detected by TaqMan nor was virus CPE observed with tissues or KF-1 cells receiving virus diluted to $10^{-5}$ or $10^{-6}$. The upper and lower limits of the analytical detection of KHV copy number estimated by serial dilutions of a KHV plasmid were 10 and $10^{7}$, respectively (Fig. 1).

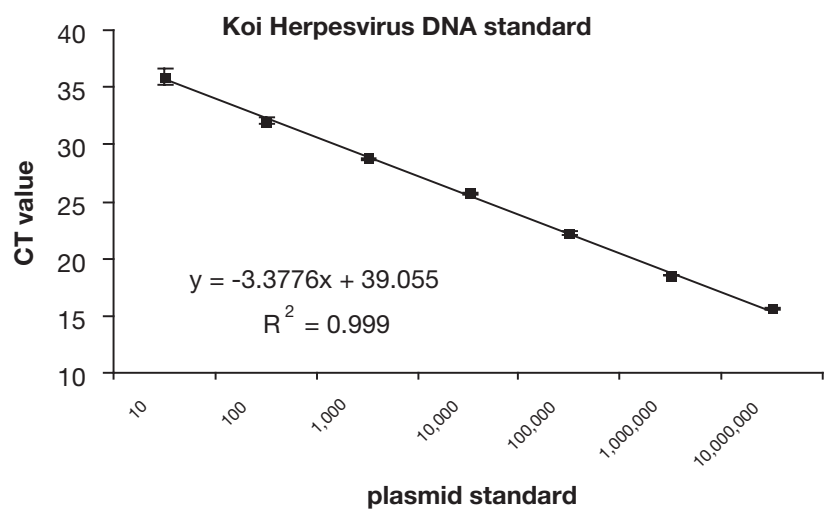

Fig. 1. Standard curve using CT values to calculate the analytic sensitivity of KHV genome equivalents with the realtime TaqMan PCR. The assay detects a range from 10 to $10^{7}$ copies of a plasmid bearing the KHV target sequences which can be used as a standard curve

\section{Quantification of KHV DNA in experimentally exposed fish during active infection}

Viral DNA was detected among KHV-exposed koi at all water temperatures tested. In contrast, no KHV DNA was detected in any of the tissues sampled from the control unexposed fish at any temperature. There was a statistically significant association of time $(\mathrm{p}<$ $0.001)$, temperature $(\mathrm{p}=0.0076)$ and the interaction between time and temperature $(\mathrm{p}<0.001)$, on the mean log transformed KHV genome equivalents. No other significant associations were found. There was a significant difference of the mean log transformed $\mathrm{KHV}$ genome equivalents between virus-exposed fish at $18^{\circ} \mathrm{C}$ compared to $28^{\circ} \mathrm{C}$ and those at $23^{\circ} \mathrm{C}$ compared to $28^{\circ} \mathrm{C}(\mathrm{p}<0.05)$.

Mortality was first observed among KHV exposed koi at a water temperature of $28^{\circ} \mathrm{C}$ at $5 \mathrm{~d}$, at $8 \mathrm{~d}$ for $23^{\circ} \mathrm{C}$ and at $14 \mathrm{~d}$ for $18^{\circ} \mathrm{C}$. There was no mortality among virus-exposed koi at $13^{\circ} \mathrm{C}$ or in any of the control unexposed groups at any water temperature. Cumulative mortality was not evaluated as fish were removed from treatment groups at prescribed sampling times.

The mucus contained considerable quantities of KHV DNA beginning as early as $1 \mathrm{~d}$ post virus exposure (Table 2). Also at $1 \mathrm{~d}, \mathrm{KHV}$ DNA was detected in several additional tissues. In comparison to other tissues, the gill, kidney and spleen, consistently had high genome copies of $\mathrm{KHV}$ at a water temperature of $23^{\circ} \mathrm{C}$, although high KHV genome copy numbers were detected in the brain, liver and intestine (Table 2). At the peak of infection at water temperatures of 18, 23, and $28^{\circ} \mathrm{C}$ KHV genome copies in most tissues examined ranged from $10^{7}$ to $10^{9}$ per $10^{6}$ host cells. 
Table 2. KHV genome equivalents per $10^{6}$ host cells as found in koi following experimental exposures to the virus at 4 water temperatures using the newly developed real-time TaqMan PCR. Not all tissues (dt) were tested at all times post virus exposure. Values marked with an "*' represent the mean of tissues from 2 fish otherwise the value is from single fish. Fish that were dead at the time of sampling are indicated by a ' $\mathrm{m}$ ', otherwise fish were alive and sacrificed for sampling. In some cases the TaqMan PCR failed to provide a value (nd)

\begin{tabular}{|c|c|c|c|c|c|c|c|c|}
\hline Temperature & Time & Mucus & Gill & Liver & Gut & Spleen & Kidney & Brain \\
\hline \multirow[t]{5}{*}{$28^{\circ} \mathrm{C}$} & $1 \mathrm{~d}$ & $1.64 \times 10^{5}$ & $1.26 \times 10^{5}$ & $6.13 \times 10^{6}$ & $1.20 \times 10^{7}$ & $3.25 \times 10^{10}$ & $5.08 \times 10^{4}$ & $1.52 \times 10^{9}$ \\
\hline & $3 \mathrm{~d}$ & nd & 0.00 & $5.68 \times 10^{4}$ & 0.00 & $9.54 \times 10^{6}$ & nd & 0.00 \\
\hline & $6 \mathrm{~d}$ & $8.87 \times 10^{8}$ & $9.18 \times 10^{8}$ & $1.74 \times 10^{7}$ & $5.87 \times 10^{6}$ & $1.16 \times 10^{8}$ & $6.38 \times 10^{7}$ & $3.26 \times 10^{7}$ \\
\hline & $8 \mathrm{~d}$ & $7.77 \times 10^{7}$ & $6.87 \times 10^{8}$ & $2.02 \times 10^{8}$ & $6.86 \times 10^{7}$ & $8.89 \times 10^{8}$ & $2.17 \times 10^{9}$ & $1.66 \times 10^{7}$ \\
\hline & $62 \mathrm{~d}$ & $\mathrm{dt}$ & $9.20 \times 10^{1}$ & $\mathrm{dt}$ & $\mathrm{dt}$ & 0.00 & $1.99 \times 10^{2}$ & $d t$ \\
\hline \multirow[t]{7}{*}{$23^{\circ} \mathrm{C}$} & $1 \mathrm{~d}$ & $3.00 \times 10^{5 *}$ & $1.62 \times 10^{3 *}$ & $2.69 \times 10^{4 *}$ & $8.05 \times 10^{1 *}$ & $1.23 \times 10^{3 *}$ & $6.83 \times 10^{3 *}$ & $3.31 \times 10^{5 *}$ \\
\hline & $3 \mathrm{~d}$ & $3.87 \times 10^{6 *}$ & $6.24 \times 10^{7 *}$ & $4.80 \times 10^{6 *}$ & $4.62 \times 10^{5 *}$ & $9.78 \times 10^{4}$ & $1.28 \times 10^{4}$ & $1.17 \times 10^{5}$ \\
\hline & $6 \mathrm{~d}$ & $8.97 \times 10^{7 *}$ & $4.26 \times 10^{8 *}$ & $1.22 \times 10^{5}$ & $1.27 \times 10^{6 *}$ & $3.90 \times 10^{8 *}$ & $1.28 \times 10^{6}$ & $3.90 \times 10^{6 *}$ \\
\hline & $8 \mathrm{~d}^{\mathrm{m}}$ & $2.24 \times 10^{8 *}$ & $1.73 \times 10^{9 *}$ & $6.52 \times 10^{8 *}$ & $4.97 \times 10^{8}$ & $7.01 \times 10^{8}$ & $2.49 \times 10^{9 *}$ & $9.66 \times 10^{7 *}$ \\
\hline & $9 \mathrm{~d}^{\mathrm{m}}$ & $1.02 \times 10^{8}$ & $1.25 \times 10^{9 *}$ & nd & $1.15 \times 10^{11 *}$ & nd & $2.31 \times 10^{10}$ & $1.54 \times 10^{6}$ \\
\hline & $10 \mathrm{~d}^{\mathrm{m}}$ & $2.10 \times 10^{8 *}$ & $3.64 \times 10^{9 *}$ & $1.90 \times 10^{10 *}$ & $3.45 \times 10^{8 *}$ & $1.78 \times 10^{9 *}$ & $2.87 \times 10^{9 *}$ & $1.80 \times 10^{8}$ \\
\hline & $64 \mathrm{~d}$ & $\mathrm{dt}$ & $1.30 \times 10^{1 *}$ & $\mathrm{dt}$ & $\mathrm{dt}$ & $0.00^{*}$ & $2.00^{*}$ & $2.50 \times 10^{1 *}$ \\
\hline \multirow[t]{6}{*}{$18^{\circ} \mathrm{C}$} & $1 \mathrm{~d}$ & $2.72 \times 10^{4}$ & $2.11 \times 10^{4}$ & $1.14 \times 10^{3}$ & $7.94 \times 10^{3}$ & $8.55 \times 10^{4}$ & $1.68 \times 10^{4}$ & $1.03 \times 10^{5}$ \\
\hline & $3 d$ & $4.81 \times 10^{4}$ & $1.58 \times 10^{5}$ & $1.81 \times 10^{5}$ & $2.02 \times 10^{6}$ & $3.23 \times 10^{4}$ & $4.75 \times 10^{3}$ & $2.63 \times 10^{7}$ \\
\hline & $6 \mathrm{~d}$ & $4.08 \times 10^{8}$ & $6.36 \times 10^{5}$ & 1.00 & $1.26 \times 10^{4}$ & $5.60 \times 10^{4}$ & $3.07 \times 10^{5}$ & $8.33 \times 10^{5}$ \\
\hline & $10 \mathrm{~d}$ & $2.88 \times 10^{8}$ & $1.47 \times 10^{8}$ & $8.52 \times 10^{4}$ & $6.79 \times 10^{7}$ & $4.95 \times 10^{7}$ & $5.84 \times 10^{8}$ & $4.33 \times 10^{6}$ \\
\hline & $15 \mathrm{~d}^{\mathrm{m}}$ & $2.71 \times 10^{6}$ & $3.48 \times 10^{8}$ & 1.00 & $9.18 \times 10^{8}$ & $1.48 \times 10^{9}$ & $3.80 \times 10^{9}$ & $5.59 \times 10^{6}$ \\
\hline & $62 \mathrm{~d}$ & $\mathrm{dt}$ & $6.00 \times 10^{1}$ & $\mathrm{dt}$ & $\mathrm{dt}$ & 0.00 & $2.80 \times 10^{1}$ & $\mathrm{dt}$ \\
\hline \multirow[t]{3}{*}{$13^{\circ} \mathrm{C}$} & $1 \mathrm{~d}$ & 0.00 & nd & nd & $d t$ & nd & 0.00 & 0.00 \\
\hline & $10 \mathrm{~d}$ & $3.50 \times 10^{5}$ & $1.28 \times 10^{4}$ & 1.00 & $6.40 \times 10^{3}$ & $3.51 \times 10^{3}$ & $1.10 \times 10^{4}$ & $3.85 \times 10^{5}$ \\
\hline & $64 \mathrm{~d}$ & $\mathrm{dt}$ & 5.00 & $\mathrm{dt}$ & dt & nd & 1.00 & 0.00 \\
\hline
\end{tabular}

\section{Quantification of KHV DNA in survivors}

Mortality had ceased in all groups by Day 24 post virus exposure and the fish remaining in each group were kept in their respective aquaria. Fish began actively feeding around $30 \mathrm{~d}$ and thereafter were normal in appearance. The experiment was terminated between Days 62 and $64 \mathrm{~d}$ post virus exposure and the kidney, spleen and gill tissues of survivors were examined for KHV DNA with the TaqMan assay. The greatest KHV DNA value of $1.99 \times 10^{2}$ genome copies per $10^{6}$ host cells was found in the gills of survivors at the $28^{\circ} \mathrm{C}$ water temperature (Table 2 ).

\section{DISCUSSION}

In the past 4 yr KHV has emerged as a significant threat to the culture and care of fancy (koi) and common carp. Means to detect the virus have been greatly improved with the development and use of conventional PCR assays as compared to isolation of the virus by cell culture or observation of virus particles by electron microscopy from fish tissues (Gilad et al. 2002, Gray et al. 2002). Conventional PCR assays, however, do not provide quantitative estimates of the virus in fish tissues, water, sediments or other potential locations where virus may be found. The TaqMan PCR reported in this study does provide a means to detect specifically KHV but not 2 related cyprinid herpes-like viruses (CyHV-1 and 2). Furthermore, the TaqMan assay was shown to provide quantitative assessments of the concentrations of viral DNA as present in several tissues from experimentally infected koi at water temperatures from 13 to $28^{\circ} \mathrm{C}$. The detection of KHV DNA in mucus suggests a role of the skin and most likely the gill epithelium early and then throughout virus infection. Spread from these external sites to involve most major internal organs precedes the onset of virusinduced mortality. Lastly, low copy numbers of KHV DNA in the tissues of survivors at $64 \mathrm{~d}$ post exposure may represent potential carriers that are not detected by conventional PCR.

A comparison of the number of genome equivalents of KHV in tissues of koi at all 4 water temperatures in this study agrees well with the mortality observed among experimentally exposed koi at these same temperatures in a second study (Gilad et al. 2003). The real-time TaqMan PCR detected KHV DNA concentrations that rose to higher levels at earlier time points at the higher water temperatures $\left(28\right.$ and $\left.23^{\circ} \mathrm{C}\right)$, temperatures at which the greatest mortality was observed in 
an earlier study by Gilad et al. (2003). These higher temperatures are within the range where most mortality is observed in naturally occurring outbreaks (Bretzinger et al. 1999, Hedrick et al. 2000, Perelberg et al. 2003). In contrast, KHV DNA was at lower levels at water temperatures of 18 and $13^{\circ} \mathrm{C}$ with no mortality observed at $13^{\circ} \mathrm{C}$. Detection of KHV DNA in fish at $13^{\circ} \mathrm{C}$ at $64 \mathrm{~d}$ post virus exposure is evidence that the virus may linger at cooler temperatures and potentially escape detection. That fish at cooler temperatures might serve as a reservoir for virus observed in spring outbreaks was demonstrated by induction of mortality due to KHV among virus-exposed fish shifted from 13 to $23^{\circ} \mathrm{C}$ (Gilad et al. 2003). In the present study viral DNA concentrations steadily increased with water temperature (Fig. 2). Thus, at higher water temperatures, at least up to $28^{\circ} \mathrm{C}$, the course of the disease should be more rapid a feature again demonstrated in the trials assessing cumulative mortality conducted by Gilad et al. (2003).

A clear and sequential spread of KHV from an initial to later target tissues could not be easily resolved. Earlier and more frequent sampling periods might be needed to more effectively demonstrate such a pattern of virus progression. That KHV DNA was detected early and then throughout infection in the mucus suggests an active involvement of the skin in viral pathogenesis. Viral replication at this site would explain the hypersecretion of mucus seen early in infection and the later pale, patchy or sandpaper appearances of the skin of fish following natural or experimental exposures to KHV (Bretzinger et al. 1999, Hedrick et al. 2000, Perelberg et al. 2003). Infectious virus shed with mucus would be a source for infection of other fish present in the same tank or pond. The important role of cutaneous tissues in herpesvirus infections are known from most animals including fish (Hedrick \& Sano 1989). An initial and then persistent involvement of the skin and gills has been observed with channel catfish (Ictalurus punctatus) infected with IcHV-1, carp infected with CyHV-1 and Japanese eels (Anguilla japonica) infected with Anguillid herpesvirus 1 (Wise \& Boyle 1985, Nusbaum \& Grizzle 1987, Sano et al. 1993, Baek \& Boyle 1996, Kobayashi \& Miyazaki 1997, Gray et al. 1999a,b, Lee et al. 1999). A systemic spread of virus, perhaps from initial sites in the skin and gills to numerous internal organs and nervous tissue occurs with the herpesviruses from catfish, carp, and eels and

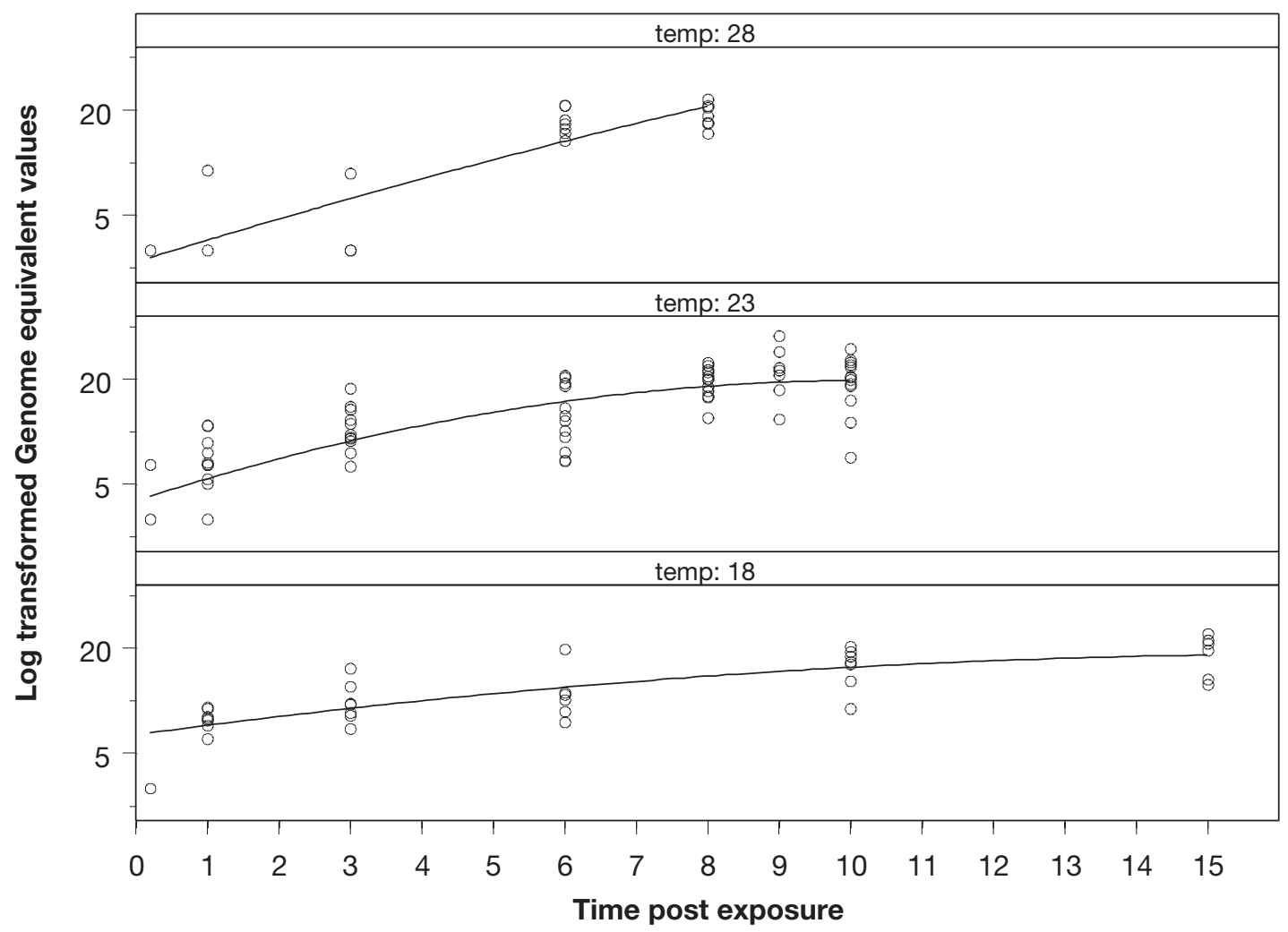

Fig. 2. Polynomial progression of genome equivalents of KHV found in koi held at 3 different temperatures $\left({ }^{\circ} \mathrm{C}\right)$ post exposure to the virus. The slope of the line represents the collapsed values of all tissues from the fish sampled at each time point 
most likely with KHV. All tissues examined in our study were found to harbor KHV DNA which supports the initial reports that the virus spreads systemically prior to the death of the fish (Hedrick et al. 2000). Freshly dead fish had KHV DNA copy numbers up to $10^{9-11}$ in the gill, liver, gut, spleen and kidney (Table 2) which was generally greater than that found among live fish at the time of sampling. These tissues are all sites of known pathological change as observed in stained sections from fish dying following natural or experimental exposures to the virus (Hedrick et al. 2000). Loss of osmoregulatory functions of the gill, gut and kidney are assumed to contribute to mortality during acute infections with KHV.

Viral DNA, but in considerably lower concentrations than during acute infection, was found in the gill, kidney or brain of fish surviving to 62-64 d post exposure to KHV (Table 2). These fish were healthy in appearance and had been actively feeding for approximately $30 \mathrm{~d}$. The low KHV DNA copy numbers found $(<2.00 \times$ $10^{2}$ per $10^{6}$ host cells) indicate that virus replication has either ceased or had greatly diminished. Alone, the detection of viral DNA is insufficient to establish whether a latent or persistent infection is present. Viral DNA of both IcHV-1 in channel catfish and CyHV-1 in juvenile carp has been detected among fish surviving either natural or experimental exposures, in some cases after 4 mo (catfish) or 35 wk (carp) post virus exposure (Sano et al. 1993, Gray et al. 1999b). Sites for viral DNA detection were blood, brain, intestines, kidney, liver and peripheral blood leukocytes in the catfish and the skin, gill, brain, cranial and spinal nerves, esophagus, liver and kidney in the carp. That KHV DNA can be present in some of these same tissues was demonstrated in our study among healthy appearing fish at 2 mo post virus exposure. Whether these fish can transmit virus upon contact with naïve fish or whether the virus can reactivate following some stressor are needed for proof that these fish are true carriers.

The TaqMan PCR for KHV described in our study provided a specific and effective means to detect and quantify the concentrations of viral DNA present in koi tissues over a range of experimental water temperatures with time, temperature and the association between them being statistically significant. The rapid and systemic spread of KHV was demonstrated by the presence of high viral genome copy numbers present in multiple tissues $1 \mathrm{~d}$ following bath exposures to the virus. That virus can persist for periods of up to at least $64 \mathrm{~d}$ suggests that a longer term relationship between virus and host can be established. When virus concentrations drop to levels demonstrated among fish in our study at $64 \mathrm{~d}$, conventional PCR tests may not provide adequate detection of viral DNA. This appears to be true in our initial comparisons of the TaqMan PCR to the PCR described by Gilad et al. (2002) and this may explain why conventional PCR has failed to reliably detect KHV DNA in fish following recovery from KHV infection (Gilad et al. 2002). Additional studies that examine potential sites for the presence of KHV DNA in koi surviving infections using the TaqMan PCR and trials that demonstrate the reactivation of the virus by subjecting these fish to natural or artificial stressors are planned.

Acknowledgements. The authors wish to thank G. Kelly, K. Kwak, J. Jeung, and R. Nix for their technical support. We also thank P. Lutes for providing valuable help with husbandry of the live fish throughout the experiment. The study was supported in part by the US-Israel BARD contract no US3166-99.

\section{LITERATURE CITED}

Arkush KD, McNeill C, Hedrick RP (1992) Production and initial characterization of monoclonal antibodies against channel catfish virus. J Aquat Anim Health 4:81-89

Baek YS, Boyle JA (1996) Detection of channel catfish virus in adult channel catfish by use of polymerase chain reaction. J Aquat Anim Health 8:97-103

Berger A, Preiser W (2002) Viral genome quantification as a tool for improving patient management: the example of HIV, HBV, HCV and CMV. J Antimicrob Chemother 49: 713-721

Body A, Lieffrig F, Charlier G, Collard A (2000) Isolation of virus-like particles from koi (Cyprinus carpio) suffering gill necrosis. Bull Eur Assoc Fish Pathol 20:87-88

Bretzinger A, Fischer-Scherl T, Oumouma M, Hoffmann R, Truyen U (1999) Mass mortalities in koi, Cyprinus carpio, associated with gill and skin disease. Bull Eur Assoc Fish Pathol 19:182-185

Clementi M (2000) Quantitative molecular analysis of virus expression and replication. J Clin Microbiol 38:2030-2036

del Cerro A, Mendoza MC, Guijarro JA (2002) Usefulness of a TaqMan based polymerase chain reaction assay for the detection of the fish pathogen Flavobacterium psychrophilum. J Appl Microbiol 93:149-156

Dhar AK, Roux MM, Klimpel KR (2001) Detection of infectious hypodermal and hematopoietic necrosis virus and white spot virus in shrimp using real-time PCR and SYBR green chemistry. J Clin Microbiol 39:2835-2845

Gilad O, Yun S, Andree KB, Adkison MA, Zlotkin A, Bercovier H, Eldar A, Hedrick RP (2002) Initial characteristics of koi herpesvirus and development of a polymerase chain reaction assay to detect the virus in koi, Cyprinus carpio koi. Dis Aquat Org 48:101-108

Gilad O, Yun S, Andree KB, Adkison MA, Way K, Willits NH, Bercovier H, Hedrick RP (2003) Molecular comparison of isolates of an emerging fish pathogen, the koi herpesvirus, and the effect of water temperature on mortality of experimentally infected koi. J Gen Virol 84:1-8

Gray LW, Williams RJ, Griffin BR (1999a) Detection of channel catfish virus DNA in acutely infected catfish, Ictalurus punctatus (Rafinesque), using the polymerase chain reaction. J Fish Dis 22:111-116

Gray LW, Williams RJ, Jordan RL, Griffin BR (1999b) Detection of channel catfish virus DNA in latently infected catfish. J Gen Virol 80:1817-1822 
Gray WL, Mullis L, LaPatra SE, Groff JM, Goodwin A (2002) Detection of koi herpesvirus DNA in tissues of infected fish. J Fish Dis 25:171-178

Groff J M, LaPatra SE, Munn RJ, Zinkl JG (1998) A viral epizootic in cultured populations of juvenile goldfish due to a putative herpesvirus etiology. J Vet Diagn Invest 10: 375-378

Hedrick RP, Sano T (1989) Viruses of lower vertebrates. Springer-Verlag, New York, p 161-170

Hedrick RP, Marty GD, Nordhausen RW, Kebus M, Bercovier H, Eldar A (1999) An herpesvirus associated with mass mortality of juvenile and adult koi Cyprinus carpio. Fish Health Newsletter, Fish Health Section, American Fisheries Society 27:7

Hedrick RP, Gilad O, Yun S, Spangenberg JV, Marty GD, Nordhausen RW, Kebus MJ, Bercovier H, and Eldar A (2000) A Herpesvirus associate with mass mortality of juvenile and adult koi, a strain of a common carp. J Aquat Anim Health 12:44-57

Jung SJ, Miyazaki T (1995) Herpesviral haematopoietic necrosis of goldfish, Carassius auratus (L.). J Fish Dis 18: 211-220

Kobayashi J, Miyazaki T (1997) Characterization and pathogenecity of a herpesvirus isolated from cutaneous lesion in Japanese eel, Anguilla japonica. Fish Pathol 32:89-95

Lee N-S, Kobayashi J, Miyazaki T (1999) Gill filament necrosis in farmed Japanese eels, Anguilla japonica (Temmick \& Schlegel), infected with Herpesvirus anguillae. J Fish Dis 22:457-463

Leutenegger CM, Klein D, Hofmann-Lehmann R, Mislin C, Hummel U, Böni J, Boretti F, Guenzburg WH, Lutz H (1999) Rapid feline immunodeficiency virus provirus quantitation by polymerase chain reaction using the TaqMan fluorogenic real-time detection system. J Virol Methods 78:105-116

Mackay IM, Arden KE, Nitsche A (2002) Real-time PCR in virology. Nucleic Acids Res 30:1292-1305

Neukirch M, Bottcher K, Bunnarjirakul S (1999) Isolation of a virus from koi with altered gills. Bull Eur Assn Fish Pathol 19:221-224

Neukirch M, Kunz U (2001) Isolation and preliminary characterization of several viruses from koi (Cyprinus carpio) suffering gill necrosis and mortality. Bull Eur Assn Fish Pathol 21:125-135

Nusbaum KE, Grizzle JM (1987) Uptake of channel catfish virus from water by channel catfish and bluegills. Am J Vet Res 48:375-377

Oh M-J, Jung S-J, Choi T-J, Kim H-R, Ranjendran KV,

Editorial responsibility: Jo-Ann Leong,

Kaneohe, Hawaii, USA
Kim Y-J, Park M-A, Chun S-K (2001) A viral disease occurring in cultured carp Cyprinus carpio in Korea. Fish Pathol 36:147-151

Overturf K, LaPatra S, Powell M (2001) Real-time PCR for the detection and quantitative analysis of IHNV in salmonids. J Fish Dis 24:325-333

Panserat S, Blin C, Medale F, Plagnes-Juan E, Breque J, Krishnamoorthy J, Kaushik S (2000) Molecular cloning, tissue distribution and sequence analysis of complete glucokinase cDNAs from gilthead seabream (Sparus aurata), rainbow trout (Oncorhynchus mykiss) and common carp (Cyprinus carpio). Biochem Biophys Acta 1474:61-69

Perelberg A, Smirnov, M, Hutoran, M, Diamant, Bejerano Y, Kotler M (2003) Epidemiological description of a new viral disease afflicting cultured Cyprinus carpio in Israel. Isr J Aquacult Bamidgeh 55:5-12

Reed LJ, Meunch HA (1938) A simple method of estimating fifty percent endpoint. Am J Hyg 24:493-497

Ronen A, Perelberg A, Abramowitz J, Hutoran M, Tinman S, Bejerano I, Steinitz M, Kotler M (2003) Efficient vaccine against the virus causing a lethal disease in cultured Cyprinus carpio. Vaccine 21:4677-4684

Rukyani A (2002) Koi Herpesvirus infection in Indonesia: Suspicion. ProMed. Jun 30, Accessed at: www.promedmail. org, archive number 20020630.4639

Sambrook J, Fritch EF, Maniatis T (1989) Molecular cloning, a laboratory manual, Vol 1, 2nd edn. Cold Spring Harbor Laboratory Press, New York, p 1.74-1.84

Sano T, Fukuda H, Furukawa M, Hosoya H, Moriya Y (1985a) A herpesvirus isolated from carp papilloma in Japan. Fish Shell Pathol 32:307-311

Sano T, Fukuda H, Furukawa M (1985b) Herpesvirus cyprini: biological and oncogenic properties. Fish Pathol 10:381-388

Sano N, Morwake M, Hondo R, Sano T (1993) Herpesvirus cyprini: a search for viral genome in infected fish by in situ hybridization. J Fish Dis 16:495-499

Schubert GH (1966) The infective agent in carp pox. Bull Off Int Epiz 65:1011-1022

Tanizawa Y, Matsutani A, Chiu KC, Permutt MA (1992) Human glucokinase gene: isolation, structural characterization, and identification of a microsatellite repeat polymorphism. Mol Endocrinol 6:1070-81

Walster C. (1999) Clinical observations of severe mortalities in koi carp, Cyprinus carpio, with gill disease. Fish Vet J 3: $54-58$

Wise JA, Boyle JA (1985) Detection of channel catfish virus in channel catfish Ictalurus punctatus (Rafinesque): use of a nucleic acid probe. J Fish Dis 8:417-424

Submitted: September 8, 2003; Accepted: April 27, 2004

Proofs received from author(s): August 6, 2004 